\title{
PRESSURE WELDING PROCESSES OF TUBULAR PARTS AND PIPE SEGMENTS
}

\author{
Attila Zsolt KENÉZ, ${ }^{1,2}$ Gyula BAGYINSZKI ${ }^{3}$ \\ ${ }^{1}$ Hilti Tools Ltd., Kecskemét, Hungary, attila.kenez@hilti.com \\ ${ }^{2}$ Doctoral School on Materials Sciences and Technologies, Óbuda University, Budapest, Hungary, \\ kenez.attila@phd.uni-obuda.hu \\ ${ }^{3}$ Donát Bánki Faculty of Mechanical and Safety Engineering, Óbuda University, Budapest, Hungary, \\ bagyinszki.gyula@bgk.uni-obuda.hu
}

\begin{abstract}
The joining of tubular (hollow, sectioned) parts to each other or for rods, sheet-like pieces and occasionally for pipe segments, is often achieved by using technology that uses a pressure welding process. These processes use mostly electrical, thermochemical or mechanical energy, and the implementation is butt, stud or projection welding. Most the pressure welding processes are suitable for the joining of different quality materials. This article summarizes the possible process variations.
\end{abstract}

Keywords: electrical energy, thermochemical energy, mechanical energy, butt welding, stud welding, projection welding.

\section{Introduction}

Figure 1. illustrates the pressure welding procedures that may be suitable for performing the tasks described in the title or abstract. It also shows the numbers according to MSZ EN ISO 4063, which deal with the naming and identification of welding and related processes, and which can be used as a kind of technical "Esperanto" for concept identification or concept interpretation independent from the mother tongue [1]. Such a "common technical language" refers to the number of weldable materials (Werkstoff-Nummer, IADS = International Alloy Designation System), or the codes of the discontinuities in the joints.

\section{Procedures and their main features $[2,3]$}

From the rotary-arc pressure type weldings that are done by a magnetically moved arc, when it comes to longitudinal field rotary-arc welding, by means of of electromagnetic coils, an axial, longitudinal magnetic field is created that closes on the hollow (tubular, closed profiled) steel workpieces that are in contact at their front surfaces. The force of

\begin{tabular}{|c|c|}
\hline $\begin{array}{l}\text { Applied energy } \\
\text { source }\end{array}$ & $\begin{array}{c}\text { The numbers of pressure welding processes } \\
\text { according to MSZ EN ISO } 4063\end{array}$ \\
\hline $\begin{array}{l}\text { electrical } \\
\text { energy }\end{array}$ & \begin{tabular}{|ll}
1 & Arc welding \\
185 & Magnetically impelled arc butt welding \\
& (length-field and cross-field rotary-arc pressure \\
& /butt/welding) \\
2 & Resistance welding \\
23 & Resistance projection welding \\
24 & Resistance flash welding \\
25 & Resistance upset welding \\
26 & Resistance stud welding \\
27 & High-frequency resistance welding \\
29 & Other resistance welding processes \\
7 & Other welding processes \\
74 & Induction welding \\
741 & Induction butt welding \\
743 & Induction HF welding \\
78 & Arc stud welding \\
785 & Capacitor discharge drawn arc stud welding
\end{tabular} \\
\hline $\begin{array}{l}\text { thermochemical } \\
\text { energy }\end{array}$ & $\begin{array}{ll}4 & \text { Pressure welding } \\
45 & \text { Diffusion welding } \\
47 & \text { Pessure flame welding } \\
49 & \text { Hot pressure welding }\end{array}$ \\
\hline $\begin{array}{l}\text { mechanical } \\
\text { energy }\end{array}$ & $\begin{array}{l}41 \text { Ultrasonic welding } \\
42 \text { Friction welding } \\
421 \text { Direct drive friction welding } \\
422 \text { Inertia friction welding } \\
423 \text { Friction stud welding } \\
44 \text { Welding by high mechanical energy } \\
441 \text { Explosion welding } \\
442 \text { Magnetic pulse welding } \\
48 \text { Cold pressure welding }\end{array}$ \\
\hline
\end{tabular}

Figure 1. Applicable pressure welding procedures 
the Lorentz law, which forces the arc (as an electric conductor) in the direction of rotation (circulation), is applied to the electric arc between the annular cooled auxiliary electrode and the contact line of the rods. The rotating arc heats the matching surfaces of the hollow pieces, and when the ever-decreasing shaping resistance decreases to the value of the axial pressure, the cohesive bond is created by the plastic hot-forming, accompanied by burr formation.

In cross-field rotary-arc pressure welding, the pieces are fitted with a gap, so that a magnetic field with a radial (cross) direction is formed in the vicinity of the gap. After creating an electric arc that bridges the gap, it also has a tangential force, so it comes into rotation (circulation) (Figure 2.a.). After the surface of the workpiece has reached the temperature of hot forming - possibly even melted in a thin layer - the arc is turned off and the welded joint is formed by axial compression (pushing the molten parts into a burr). In rotary-arc welding, in most cases, it is sufficient that only one piece is hollow (thin-walled, tube-like), the other can be solid (rod-like) or even plate (flat).

Unlike resistance spot welding, electrodes have only two functions for projection welding: pressure transfer and power supply. The third task - the concentration of the current - is fulfilled by the natural or artificial shape of the workpieces (Figure 2.b.). During projection welding of the artificial butt usually formed by plastic forming or machining -, a seam (section) is formed at each butt. Resistance stud welding is a "special butt welding" where current concentration results from the well-formed face of a solid or tubular weld to be welded (Figure 2.b.). The pin holder and the counter electrode are used to transmit the compressive force and to supply the current.

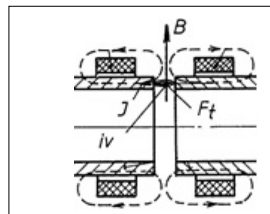

a)

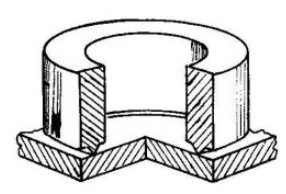

b)
Figure 2. Cross-field rotary-arc pressure welding and projection welding (stud welding)

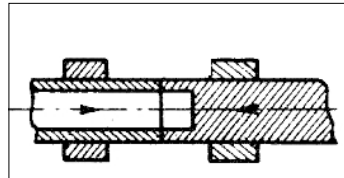

a)

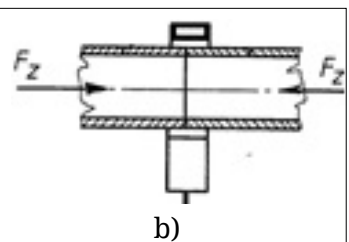

b)
Figure 3. Resistance and induction butt welding
During upset welding - the workpieces are compressed at their front surfaces (Figure 3.a.), and passed through high current - the combined heat and force create a high degree of plastic deformation, creating a cohesion relationship between the two materials. The surface contamination effective pressure in the burr is only possible with a smaller cross-section. When flash welding, the current-connected parts are compressed and removed after a certain period of time. Heating and contamination removal are assisted by a locally generated electric arc, while melting the surface layer. Until the next contact, the generated heat by heat transfer will also warm the material parts up that are slightly further away from the surface. Surface melting takes place in a thin layer on a large surface with low specific energy consumption. Often, this cycle is repeated a few times, and the pieces are then compressed. This process is mainly applicable to larger cross-sections.

In induction butt welding or coil-inductor resistance butt welding, the eddy currents can be excited at the welding site with the high-frequency current, mostly coil inductor (Figure 3.b.) positioned symmetrically in relation to the joining surfaces in the compressed workpieces. The high local current density created by the eddy currents heats up the narrow zone along the contact surfaces, and then the cohesive bond is formed by compressing these parts.

In capacitor discharge pulse welding [4], the required energy is fed to the special transformer connected to the workpiece via a ticker switch to the workpiece. The process is characterized by the following process characteristics: steep increase in current, high welding current, short (millisecond) welding time, low specific heat input, low network load, high reproducibility. In addition, workpieces of different material thickness, different material qualities (e.g. steel, brass), stainless steels, thin sheets and galvanized workpieces can be welded. Although there is no need for filler material to form the join in the process, however, one of the surfaces to be joined prior to welding (preparation) requires indention or grooving (Figure 4.).

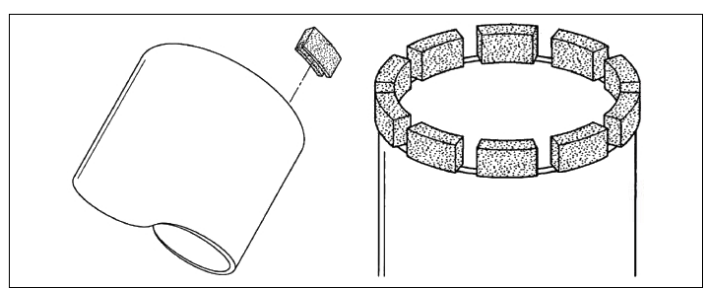

Figure 4. Example of capacitor discharge pulse welding 
In ultrasonic welding the vibration movement of the amplitude of the ultrasound increased by an acoustic transformer which is induced by an electrostriction or magnetostriction effect is transferred by the sonotrode to the smaller of the assembled pieces. The sonotrode vibrates with this piece, and conveys the press force to provide a welded join. It is possible to combine the same or different material qualities. In ultrasonic circular welding (Figure 5.a.), the alternate movement of the tubular sonotrode around the axis of the tube is e.g. it performs three vibration units equipped with an acoustic transformer, and thus a joining zone of almost the same size and shape as the front surface of the sonotrode is formed during welding.

In the most well-known version of the friction welds, the two rotational symmetric pieces (rods, tubes) to be joined are rotated in a compressed state relative to one another by a continuous drive or by inserting a flywheel. When the entire surface is covered by friction cleaning, heating and excitation, the rotation is stopped quickly and the pieces are compressed, because only in this way can a good join between the two materials be made. If the time for "preheating" ("rubbing") is set, then it is time-controlled and if the degree of "shortening" generated by the press force during preheating is set, then it is a road-based friction welding. Because of rotation and upsetting, a characteristic shaped burr is formed, which (if necessary) can be machined without the joining being weakened. In vibrating friction welding, the pieces of material under constant compression are vibrated as a result of a high relative speed difference and low amplitude alternating motion. The combined effect of generated heat, surface pressure and braking at the right time create a cohesive bond between the two pieces.

During friction stud welding, the solid or tubular stud to be welded is pressed onto the base plate during rotation (Figure 5.b.), the friction heat warms the material parts close to the contact surfaces, while the surface impurities are also destroyed, facilitating surface cleansing and surface activation. As an effect of the plastic deformation of the materials near the surface, a partially cohesive bond

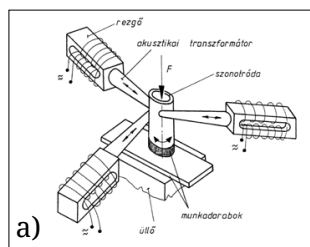

b)

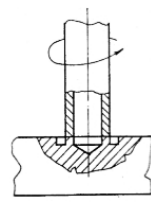

Figure 5. Ultrasonic circular welding and friction stud welding is formed between the two pieces, which, however, is continuously shearing due to the relative displacement. This process, which requires significant energy investment, results in significant heat generation, which heats the higher volume of material near the surface. When bond formation is expanded to the entire surface, the relative displacement (rotation) is stopped very quickly and the pin is pressed onto the base plate by axial compression.

In blast welding with overlapping (Figure 6.a.) by the use of explosive materials, the workpieces (e.g. tubes) that are aligned with gap or overlapping, collide with high speed, at the same time compressive stresses perpendicular to surfaces and sliding stresses parallel to surfaces build up simultaneously. The compressive stresses are necessary for the surface atoms to reach a near grid parameter distance. The sliding tensions through the plastic shaping result in a correct crystal lattice orientation of the contact metallic parts and the formation of the conditions of the cohesion bond.

During magnetic pulse welding, a high capacity condenser plant is flushed through the forming coils. The field shaping effect of the high current flowing through the coils creates a very high magnetic induction at the welding site (Figure 6.b.). In the workpiece to be welded due to the current induced and the interaction of the magnetic field, a radial direction dynamic force is created. The force resulting from the discharge of the condenser plant in an extremely short time causes the workpieces to collide like as in blast welding, and a welded bond is formed due to the plastic deformation of the surface material parts, especially between the interlaced surfaces.

During diffusion welding, the materials to be bonded are heated in compressed condition to a temperature close to their melting point in a vacuum (possibly in a neutral shielding gas atmosphere) (Figure 7.a.). By the simultaneous action of high temperature and pressure - at the point-like surface material parts - a permanent flow (creep) occurs, causing the workpieces to contact each other on a gradually growing surface. The atoms of deforming surfaces, which are in the state of excitation caused

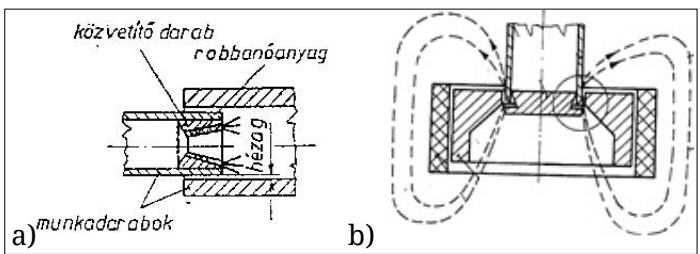

Figure 6. Blast butt welding and magnetic pulse welding 


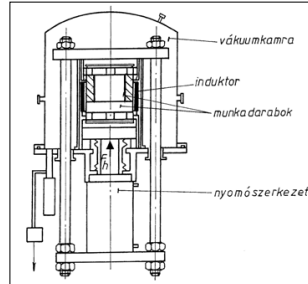

a)

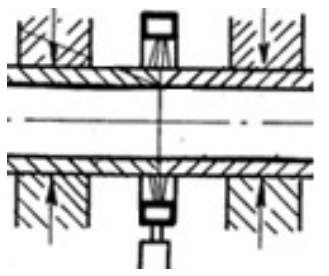

b)
Figure 7. Diffusion welding and Pressure flame welding

by plastic deformation and temperature, through volumetric diffusion that causes grain border migration and pore loss, get within a grid parameter distance to each other, resulting in a cohesive bond. The special feature of diffusion welding is that next to the welding of steels and non-ferrous metals it is suitable for special metallic materials, metal combinations and even metal-ceramic bonding. Intermediate materials are used in some metal combinations if the two materials do not dissolve in each other or if they would form a brittle or corrosion-prone phase.

During closed gap pressure flame welding, the hollow workpiece contact surfaces, which are fitted without gap by means of an openable ring burner, are heated by with a flame from an acetylene-oxygen gas mixture (Figure 7.b.), and then compressed with a material-dependent pressure. With opengap flame welding, the double-sided flat burner placed in the gap between the solid workpieces is used to heat the surfaces to be bonded to the hot forming temperature. The burner is then removed and the pieces pressed together with the correct pressure.

During ahead flow cold-pressure welding, due to the high degree of plastic deformation in the multi-axis pressure tension state, a cohesive bond extending over the entire contact zone is formed. With Flow Stamp (Fluid Needle), depending on the design of the workpieces, it is possible to produce a solid or tubular (hollow) product (Figure 8.a.) provided that the various materials have a high degree of deformation. Certainly, due to forming below the recrystallization temperature, a significant hardening should be expected, which may have a strength increasing effect.

In solver welding, the insert ring is used as filler material, which is a powder metallurgical product consisting of iron powder, Mn-alloy solver and flux, is placed between the front surfaces of the two thin-walled, small diameter steel tubes to be joined. At constant pressure, heating the welding

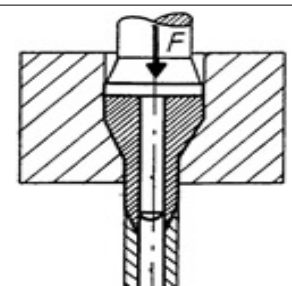

a)

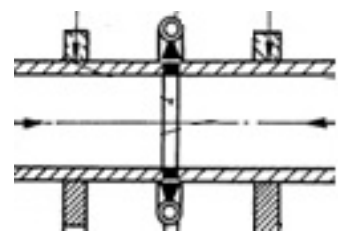

b)
Figure 8. Cold-pressure welding with ahead flow and Hot pressure welding

place with an openable ring burner, the weld is formed by the effect of mutual dissolution (Figure 8.b.) so that the solvent melts at a lower temperature and begins to dissolve the iron (raw material) and then at a certain concentration solidifies into the welded joint, but after reaching the higher welding temperature, the raw material dissolves the solvent, and then the alloy begins to melt, therefore the welding must be completed before the melting is complete.

\section{Conclusion}

The possible basic variants of pressure welding methods with various energy sources are butt, stud and projection welds. They are suitable for the welding of tubular, hollow parts and some types of them are suitable for the welding of pipe segments as well. In this case, the task is not pipeline construction, but assembly welding. In this article, we have explored opportunities to help find a solution for a specific task. An important aspect is that, in most cases, when calculating the expected burr formation, the prefabricated pieces that are to be welded must be made longer so that the required size is achieved after pressure.

\section{References}

[1] Bagyinszki Gy:: A hegesztés és rokoneljárásai rendszerezése. Hegesztéstechnika 13/2. (2002) 29-35.

[2] Bauer F.: Hegesztési eljárások. (Szerk. Bagyinszki Gy.), Tankönyvkiadó, Budapest, 1991

[3] Bagyinszki Gy., Bitay E.: Hegesztéstechnika I. - Eljárások és gépesítés. Erdélyi Múzeum-Egyesület, Kolozsvár, 2010.

https://eda.eme.ro/handle/10598/15437

[4] Kenéz A. Zs., Bagyinszki Gy.: Kötőtechnológiák alkalmazhatósági vizsgálata gyémántszegmenses fúrókoronákhoz. In: A XIX. Műszaki tudományos ülésszak előadásai, Kolozsvár, Románia, Műszaki Tudományos Közlemények 10. (2018). https://eda.eme.ro/handle/10598/31162 